\title{
Erken Dönemde Hıristiyan Karşıtı Söylemin Ortaya Çıkmasını Hazırlayan Sebepler
}

\author{
İBRAHIM KAPLAN \\ DR., İNÖNÜ Ü. İLAHIYAT FAKÜLTESI \\ e-mail: ikaplan43@hotmail.com
}

\begin{abstract}
Factors Behind the Appearance of Counter Christianity Discourse in Early Period. The most important factor behind the appearence of the counter Christianity discourse in early period is mostly composed of some teological concerns. Moreover, political and socio-cultural influences triggered the counter Christianity discourses.In this context, translation activities brought richness in the content and methodology of the discourse. The main presupposition or acceptance behind the counter christianity discourse is a conception as: "the truth is one, but superstitious is more". The attempt of making clear what constitutes the truth and the superstitious declaring "the truht has come and the superstitious has disappeared" was the most important factor behind the counter christian discourse. The other reasons contributed to the remembrance of this presupposition.
\end{abstract}

key words: Anti-Christian Polemic, Theological Releationship, Kalam, Christianity.

Giriş

Yegâne kurtuluş yolu olarak ortaya çıan bütün dinler, kendilerinden önceki dinî sistemleri lağv etmişler, sonrakileri ise eleştirel bir tarzda ele alıp reddetmişler; böylece kendi dinî elemanlarını savunmacı bir tarzda diğerlerinden üstün ve farklı tutarak kendilerine ait kurtuluş kutsalını geliştirmişler$\operatorname{dir}^{1}$. Dolayısıyla, her din kendi teolojisini oluştururken, şu veya bu şekilde,

1 Mustafa Ünal, "Kur'an'da Hıristiyanlara Yönelik Teolojik Eleştirilerin Fenomenolojisi”, Müslümanlar ve Diğer Din Mensupları, TDTD Yay., Ankara, 2004, s. 214. 
ötekini de dikkate almıştır. Fakat dinlerin ötekine ilgisi, genellikle onun geçersizliğini ya da tarihselliğini ortaya koymak suretiyle kendisinin doğruluğunu ispatlamak şeklinde olmuştur. Başka bir ifadeyle, Tanrının ne olduğunu ortaya koyma çabası, zorunlu olarak, ne olmadığının da araştırılması ihtiyacını ortaya çıkarmıştır. Bu da kaçınılmaz olarak, öteki dinlerin Tanrı kavramlarının ortaya konulmasını gerekli kılmıştır. Aynı ihtiyaç, dinle ilgisi bulunan, peygamberlik, vahiy vb konular için de geçerlidir. Nitekim Kur'an da, indiği coğrafyadaki dinler hakkında bilgiler sunmuş, hatta karşılaştırmalar yapmış, böylece kendi din tanımını ortaya koyduktan sonra, dolaylı olarak hakkında bilgi vermediği dinlerin de geçersizliğini ilan etmiştir ${ }^{2}$. Bu bağlamda Kur'an'da zikri geçen dinlerden biri de Hıristiyanlıktır. Kur'an, bir yandan Hıristiyanlık hakkında bilgiler verirken diğer taraftan Hıristiyan teolojisini ciddi bir eleştiriye tabi tutmuştur. Kur'an'daki söz konusu eleştirilerle başlayan Hıristiyan karşıtı söylem, özellikle H. III. asrın başlarında içerik ve yöntem açısından çeşitlenmiştir. Bu dönemde, genelde reddiye tarzında kendini gösteren Hıristiyan karşıtı söylemin hangi şartların ürünü olduklarının belirlenmesi, Kelam araştırmaları açısından farklı bir bakış açısını ortaya koyacaktır. Zira, Kelam ilminin tarihi gelişimi teolojik ilişkiler açısından da ele alınıp değerlendirilmeye muhtaç görünmektedir. Bu makale, erken dönemde Hıristiyan karşıtı söylemin ortaya çıkmasını hazırlayan sebeplerin ortaya konulması ve değerlendirilmesiyle sınırlıdır. Kanaatimizce, bu sebeplerin ortaya konulması, oluşum dönemi Kelamının işlevi, muhteva ve yöntemindeki gelişmeler hakkında önemli ipuçları sağlayacaktır.

\section{Teolojik Kaygılar}

Kur'an'da, İsa'ya gelen vahiy ve onun peygamberliği, Hıristiyanların vahiy ve peygamberlik anlayışından farklı tarzda tasvir edilir. Kur'an'a göre, Hz. İsa da dahil, bütün peygamberler aynı içeriğe sahip mesajı iletmekle görevlendirilmişlerdir. Ancak, Hıristiyanlar, kendilerine vahyolunandan farklı şeyler söylemişler ${ }^{3}$, verilen mesajın önemli bir bölümünü unutmuşlar ve kitaptaki pek çok şeyi gizlemişlerdir ${ }^{4}$. Diğer taraftan onlar, "Mesih Allah'ın oğludur" demek, Allah'ı bırakıp Meryemoğlu İsa'yı rab edinmek ${ }^{5}$, tevhid inancını b1rakıp üçlü Tanrı inancını kabul etmek ${ }^{6}$ suretiyle Allah'ın kitabını tahrif et-

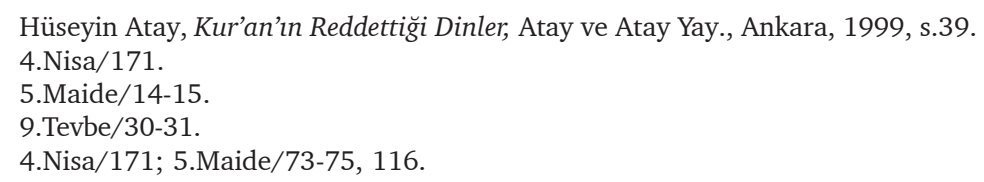


mişler ve kendi elleriyle yazdıkları kitabın Allah katından geldiğini iddia etmişler ve bu yolla insanları Allah'ın yolundan engellemişlerdir ${ }^{7}$. Yine H1ristiyanlar, Hz. Muhammed'in geleceğini haber veren ayetleri gizlemişlerdir $^{8}$. Hıristiyanlar, gerçek İncil'de bulunan bazı ayetleri gizlemenin yanında, bazı ayetleri de yanlış yorumlamışlardır. Hz. İsa'nın babasız doğumu bunlardan biridir9 .

Genel olarak, Hıristiyanlık söz konusu olduğunda Kur'an'ın, bir yandan gerçek Hıristiyanlık hakkında bilgiler verirken, diğer taraftan da mevcut Hıristiyanlık için eleştiriler yönelttiği gözlenmektedir. Sözü edilen teolojik eleştirilere rağmen Kur'an, Yahudi ve Hıristiyanları Ehl-i Kitap olarak kabul etmekte, onları ortak oldukları bir kelimede birleşmeye davet etmektedir. Dolayısıyla Kur'an, bir taraftan Yahudi ve Hıristiyanları Ehl-i Kitap tanımlamasıyla bir anlamda kendisinin selefi görürken, diğer taraftan da onların Allah tarafından gönderilen kitapları tahrif ederek doğru yoldan uzaklaştıklarını söylemektedir. Dolayısıyla İslâm, hem insanlığın son dini olması ve kendi anlayışı çerçevesinde bütün insanlığın dini haline gelmeyi hedeflemiş olması sebebiyle, hem de Ehl-i Kitapla olan halef-selef ${ }^{10}$, başka bir ifadeyle kalıtsal $^{11}$ ilişkisi sebebiyle Yahudi ve Hıristiyanlarla diğerlerine göre daha yakın teolojik ilişki içerisinde görünmektedir. Tatar'ın ifadesiyle: "Kur'an'ın bir taraftan evrensellik iddiasında bulunmast diğer taraftan da Yahudiler ve Hiristiyanlart Ehl-i Kitap olarak tanımlamast, yani bir taraftan kendi Tevhid anlayışı doğrultusunda evrensel otoritesini ileri sürmesi diğer taraftan Tevrat ve İncil gibi metinlerin kısmi otoritesini kabul etmesi bir gerilime ve diyalektik düşüncenin oluşmasına yol açmaktadır." 2 Bir anlamda, hem teolojik bir birlikteliği, hem de farklılığı ya da ayrışmayı içinde barındıran bu ilişki tarzı Müslümanların dikkatini bu dinlere, özellikle de Hıristiyanlığa yöneltmiştir. Ancak öyle görünüyor ki, genelde öteki din ve inanışlara, özelde de Hıristiyanlığa karşı ilk Müslümanların ilgisi oldukça sınırlı kalmıştır. Çünkü, din hakkında ilk elden bilgi alma gibi bir şansa sahip olan sahabenin inandıkları

7 İbn Cerir et-Taberî, Câmiu'l-Beyan an Te’vili'l-Kur'an, Mısır, 1374/1954, X, s. 117; Elmalılı Muhammed Hamdi Yazır, Hak Dini Kur'an Dili, Eser Neş., ty. IV, s. 2519.

8 61.Sâf/6.

9 Kur'an'ın Hıristiyan teolojisine yönelttiği eleştiriler hakkında bir değerlendirme için bkz., İbrahim Kaplan, Erken Dönem Müslüman-Htristiyan Teolojik İlişkileri, (A.Ü.S.B.E., Basılmamış Doktora Tezi), Ankara, 2006, s. 43-54.

10 Muhammed Abdürrauf, "İslâm Açısından Musevilik ve Hıristiyanlık”, İbrahimî Dinlerin Diyalo$\breve{g} u$, ed. İsmail R. Farukî, çev., Mesut Karaşahan, Pınar Yay., İstanbul, 1993, s. 53.

11 R. Pettazoni, "Monoteizmin Teşekkülü”, çev., Fuat Aydın, SAÜIFD, 2/2000, s. 290.

12 Burhanettin Tatar, Kelam'a Göre Öteki Dinlerin Durumu, İslam ve Öteki Dinlerin Doğruluk/Kurtarıcılık ve bir arada Yaşama Sorunu, ed., Cafer Sadık Yaran, Kaknüs Yay., İstanbul, 2001, s. 287. 
Tanrıyı tanımlama gibi bir zorlukla karşılaşmadıklarını söyleyebiliriz. Aynı zamanda, müşriklerin sistematik bir Tanrı tasavvuruna sahip olmaması onların bu yöndeki kafa karışıklığını önlemekteydi. Yine Yahudilerin, takip ve sürgünler neticesinde maruz kaldıkları coğrafî dağınıklık, onlar için fikrî dağınıklı̆̆ı ve çözülmeyi de beraberinde getirmişti. Bu bölge ve tarihin önemli dini durumundaki Hıristiyanlığın, Bizans gibi güçlü bir devletin resmi dini olmasına rağmen kendi içindeki mezhep çatışmaları yüzünden Müslümanlara yönelik fikri ve askeri mukavemet gösterebilecek güçte olmaması da Müslümanların öteki dinlere ilgisiz kalmasına sebep oluyor ya da öteki dinlere tepki göstermesini gerektirmiyordu ${ }^{13}$. Kısaca ifade etmek gerekirse, bu dönemde, Tanrı'nın ne olduğu yeterli oluyor, ne olmadığı sorusu ciddi anlamda gündeme getirilmiyordu. Ya da bu konuda zihinlerde oluşan soruların cevabı için Kur'an'daki ilgili ifadeler ve peygamberin açıklamaları yeterli oluyordu.

Hz. Peygamberin vefatından kısa bir süre sonra, henüz I. yy'da, Mezopotamya, Şam, Mısır, İran ve kısmen de Hindistan'ı fetheden Müslümanlar bu hızlı yayılma ve genişlenmeyle birlikte gelen iki ciddi problemle karşı karş1ya kalmıştır denilebilir; Kitlesel İslâmlaşmanın getirdiği uyumsuzluk sorunu ve bölgedeki inanç ve felsefi düşünüş sistemleriyle fikri alanda çatışma ${ }^{14}$. Dolayısıyla, sahabe döneminde Tanrının ne olduğu onlar için yeterli olurken, şımdi ne olmadığının açıklanması da ayrı bir ihtiyaç olarak belirmekteydi.

Coğrafyanın genişlemesiyle karşılaşılan kitlesel İslamlaşmanın getirdiği uyumsuzluk sorunu eğitim yoluyla aşılmaya çalışılırken, bölgedeki inanç ve felsefi düşünüş sistemleriyle fikri alanda mücadele, karşısında bölge kültürünü dikkate alma ya da almama şeklinde iki tür tavrın geliştiğine şahit olmaktayız. Birinci tavrı tercih edenler daha çok Selefî ve Ehli Hadis anlayışında olan, Kur'an ve hadislerin verdiği malumatı yeterli görüp reddetmek şeklinde bile olsa diğer düşünce ve inançlarla ilgilenmeyi bid'at sayan kimselerden oluşuyordu. Bu tavrın temsilcileri, Hz. Peygamber döneminde dinin mükemmel şekline kavuştuğundan hareketle başka din ve kültürleri dikkate almanın gereksiz olduğunu, dolayısıyla her konuda olduğu gibi bu konuda da Kur'an ve sünnete bağlılığın yeterli olacağı düşüncesini taşıyordu. İkinci tavrı benimseyenler ise, diğer inançlarla fikrî alanda mücadelenin kaçınılmaz olduğunu, er ya da geç gerçekleşecek olan bu mücadeleden ga-

13 Karen Armstrong, Tanrı'nın Tarihi, çev., Oktay Özel-Hamide Koyukan-Kudret Emiroğlu, Ayraç Yay., Ankara, 1998, s. 149-150; Cağfer Karadaş, Bakulllânîye Göre Allah ve Âlem Tasavvuru, Arasta Yay., Bursa, 2003, s. 80.

14 Karadaş, a.g.e., s. 80. 
lip çıkabilmek için öncelikle bunların bilinmesi, ardından da İslâm inancının sistematize edilmesi gerektiğini savunuyordu. Aynı zamanda bu, bölgede tutunabilmenin de bir gereği olarak görülüyordu ${ }^{15}$.

Zaman ilerledikçe kitlesel İslamlaşmanın getirdiği sorunlar İslâm toplumunda inanç parçalanmaları ve buna paralel olarak da İslam'ın temel ilkelerine aykırı bazı anlayışların oluşmasına sebep oldu. Nitekim hicri birinci asrın sonuna doğru İslâm toplumunda bir yekün oluşturmaya ve tehdit unsuru olmaya başlayan aşırı gruplar boy göstermeye başlamıştı. M. Abduh bu durumu şu şekilde özetlemektedir; "Çeşitli dinlere mensup insanlardan bazlları, tam olarak inanmamalarına rağmen, İslâm etiketini aldılar. İlk dinlerine ait inançların beraberlerinde getirerek İslâm'a girdiler ve eski dinleriyle girdikleri bu yeni din arasında birleştirici bir bă̆ bulacaklarını umdular. Böylece büyük fitne kasirgasından sonra şüphe kasirgaları ortaya çıtı."16

İşte bu dönemde, önceki dinlerini terk ederek İslâm'ı seçenlere inanç ilkelerini algılayabilecekleri tarzda sunma görevini Kelamcıların yüklenmiş olduklarını görmekteyiz. Öteki dinlerin Kelam'ın bir konusu olarak belirmesi de bir anlamda, yeni Müslümanların bu gel-gitlerine son vermek, yani inananların zihninde oluşabilecek şüpheleri giderme çabası olmalıdır. Yine, buralarda iyi yetişmiş Hıristiyanlarla karşılaşan Müslümanlar, İslam'ın ilkelerini ileri düzeyde savunma gereğinin farkına varmışlard $1^{17}$.

Buna ilave olarak, mal, şöhret, şahsî çıkar ve İslâmiyet'i içten yıkmak ve böylece asıl inandıkları dinin intikamını almak gibi sebeplerle din değiştiren insanların verebileceği zararların da önüne geçmek gerekiyordu. Bu insanların Müslümanların zihinlerinde sinsice oluşturabileceği tereddütlerin ve

15 Karadaş, a.g.e., s. 80-82.

16 Muhammed Abduh, Tevhid Risalesi, çev., Sabri Hizmetli, Fecr Yay., Ankara, 1986, s. 80; Abduh'un yukarıdaki açıklamaları; "Ey Muhammed! Bedevîler iman ettik dediler. De ki; İnanmadınız ama boyun ĕgdik deyin. İnanç henüz kalplerinize yerleşmedi. Şayet Allah'a ve peygamberine itaat ederseniz, yüce Allah işlediklerinizden bir şey eksiltmez"şeklindeki 49.Hucurat/18.ayetini hatırlatmaktadır. Kelam kitaplarında genelde İslam-iman ve amel-iman ilişkisi bağlamındaki tartışmalarda sıkça müracaat edilen bu ayet, aynı zamanda önceki inancını bırakıp da Müslüman olanların psikolojisini yansıtması açısından da değerlendirilmeye tabi tutulması gereken bir mesaj görünümündedir. Eski inançlarını bırakıp İslâmiyet’i seçenlerin kendi iç dünyalarında bir takım gel-gitler yaşamaları gayet doğaldır. Onların, ikrarlarından hemen sonra önceki dinleriyle zihinsel irtibatlarının da kesileceğini düşünmek yanlış olacaktır. Çünkü bir insanın, batıl da olsa, zihninde ve kültüründe yer edip bütün benliğini saran bir inancı bir anda terk etmesi kolay değildir. Sanırız ayette bu duruma da gönderme yapılmaktadır. Ayetin ikinci kısmındaki, onların amellerinin boşa çıkmayacağına vurgu yapan ifadeleri de, onların üzerinde psikolojik bir tesir bırakarak yeni inançlarında sabit kılmayı hedefleyen ifadeler olarak değerlendirebiliriz.

17 W. Montgomery Watt, Günümüzde İslâm ve Hiristiyanlık, çev., Turan Koç, İz Yay., İstanbul, 2002, s. 19. 
bulanıklığın boyutları herhalde çok büyük olacaktı. Nitekim Kelam İlmi’nin gayesine göre tarifi yapılırken özellikle bu hususa, sebebi ne olursa olsun Müslümanın zihninde oluşabilecek şüphelere, dikkat çekilmiştir. Kesin deliller getirerek ve şüpheleri gidererek dinî akideleri ispat etme ${ }^{18}$ gayesine ulaşabilmek için Kelam, doğal olarak öteki inanç ilkeleri ile İslâm'ın ilkelerini karşılaştırma yoluna gitmiştir. Bu sayede de öteki dinler Kelam İlmi'nin bir ilgi alanı olarak belirmiştir. Nitekim, bir yandan farklı inanç ve dinlerle karşlaşma, diğer taraftan da tercüme hareketleriyle bir başka kültür ve geleneğin muhtevasından haberdar olma, İslâm vahyine dayalı bir düşünceyi alternatif olarak sunmak ve tevhid geleneğini her türlü olumsuzluktan korumak uğruna farklı din ve inançları tanımayı zorunlu kılmaktaydı. Dolayısıyla, İslam'ın inanç ve esaslarını konu edinen Kelam, alternatif ve evrensel bir inanç sistemi olarak ortaya çıkmanın bir sonucu olarak öteki dinleri de araştırma konusu haline getirmek zorunda kalmıştı. Bu anlamda, başlangıçta doğrudan doğruya dinî akideleri teşkil eden hususlar (mesâil) aynı kalırken, bu akidelere mebde teşkil edenler (vesâil) zaman içinde değişime uğramış ${ }^{19}$, İslâm'ın mükemmel ve evrensel bir din olduğunu ortaya koyma sadedinde Hıristiyanlık, İslâm'ın karşısında duran bir inanç sistemi olarak araştırma konusu yapılmıştır.

Bunun yanında, eski inançları ile yeni inançlarını harmanlayıp antropomorfik bir Tanrı tasavvuru oluşturan müşebbihe ${ }^{20}$ ve mücessime ${ }^{21}$ gibi aş1rı gruplarla bunlara tepki olarak ortaya çıkan ${ }^{22}$ ve Allah'ın bütün sıfatlarını

18 Seyyid Şerif Cürcânî, Şerhu’l-Mevâkıf, İstanbul, 1239, s. 11; İzmirli İsmail Hakkı, Yeni İlm-i Kelam, Evkâf-1 İslâmiyye Matbaası, İstanbul, 1339-1341, 5.

19 Cürcânî, a.g.e., s. 12; Taftazânî, Şerhu'l-Makâsıd, thk, Abdurrahman Umeyra, Beyrut, 1989, I, s. 173; İzmirli, a.g.e., s. 7; Mustafa Sinanoğlu, "Diğer Dinlerin Kelam İlmine Konu Olması", İlahiyat Fakülteleri Kelam Anabilim Dalı Eğitim-Öğretim Meseleleri Koordinasyon Toplantısı-II, MÜifV Yay., İstanbul, 1998, s. 109-110.

20 Allah'ın sıfatlarını insanın sıfatlarına benzeterek insan biçimli bir Tanrı anlayışı oluşturan Müşebbihe hakkında geniş bilgi için bkz., Ebu'l-Feth Muhammed b. Abdülkerim eş- Şehristânî, el-Milel ve'n-Nihal, thk., Muhammed Fehmi Muhammed, Beyrut, 1992, I, s. 92-98; Ebu Mansur Abdülkâhir el-Bağdâdî, el Fark beyne'l-Frrak, thk., Muhammed Muhyiddîn Abdülhamid, elMektebetü'l-Asriyye, Beyrut, 1993, s. 225-230.

21 Kurucusu olduğu kabul edilen Muhammed b. Kerram'dan (ö. 255/869) dolayı Kerrâmiye diye de isimlendirilen Mücessime, Allah'ın cisim olduğundan hareketle Allah'a mekan, cevher ve ağırlık atfetmiştir; bkz., Ebu'l-Hasan el-Eş'ârî, Makâlâtü'l-ìslâmiyyîn ve İhtilâfü'l-Musallîn, thk., Muhammed Muhyiddin Abdülhamid, el-Mektebetü'l-Asriyye, Beyrut, 1995, I, s. 281-290.; Şehristânî, a.g.e., I, s. 99-105; Bağdâdî, a.g.e., s. 226-230.

22 Mukatil b. Süleyman'ın teşbih anlayışına tepki olarak, çă̆daşı Cehm b. Safvân gerek sıfatları reddetme gerekse Allah'ı tenzih konusunda aşırı hassas davranarak tam ters tarafta bir aşırılığın temsilcisi olmuştur. Ebu Hanife, Cehm'in teşbihi nefyetmede gösterdiği aşırılığın Mukatil'in teşbih anlayışına bir tepki olduğunu söyler. Bkz., Cemaleddin Kasımî, Târihu'l-Cehmiyye ve’l-Mu'tezile, Mısır, 1331, s. 8; Ali Sami Neşşâr, İslâm'da Felsefi Düşüncenin Doğuşu, çev., Osman 
geçersiz kılan Cehm b. Safvân (ö. 128/754) ${ }^{23}$ gibi aşırılarla fikrî mücadele artık kaçınılmaz olmuştu. Şehristânî, teşbih ve tecsim anlayışlarının ortaya çıkmasında Müslüman olan Yahudilerin uydurma haberlerinin etkisinden bahsetmektedir ${ }^{24}$. Kur'an'ın, vahyedildiği gibi korunması hususundaki Müslümanların hassasiyeti onu tahrif edemeyeceklerini anlayan Yahudileri, bu kez hadis sahasına yöneltmiştit ${ }^{25}$. Aynı şeye Hıristiyanların da teşebbüs ettiğini söylemek zor değildir.

Yahudi ve Hıristiyanlar ilâhî vahiyle peygamberin ve diğer din adamlarının sözlerini birbirine karıştırmışlar, bunun neticesinde İslâm'ın muharref olarak nitelediği Tevrat ve İncil ortaya çımıştı. Bu tarihi tecrübeden hareketle Hz. Ömer, aynı şeyin Müslümanların da başına gelmesi endişesiyle hadislerin tedvînine izin vermemişti. Hadis rivayetleri konusunda oldukça hassas davranan Hz. Ömer döneminde hadislere uydurma sözlerin ve iftiraların karışması pek kolay olmazken, Hz. Osman döneminde uydurma hadislerin yayılması için müsait bir ortam oluşmuştu. Bu müsait ortamdan sonuna kadar yararlanan Yahudiler, bütün maharetlerini kullanarak hadislere isrâilayâtı ithal ettiler. Önceleri imamet ve siyaset renginde olan isrâiliyât daha sonra teşbih ve tecsim rengine bürünmüştü. Nitekim, teşbih ve tecsimle ilgili rivayetlerin çoğunun Tevrat kaynaklı olduğunu tespit etmek zor değildir ${ }^{26}$. Bağdâdî̀ye göre de, önceden Yahudi iken Müslüman olan Abdullah ibn Sebe $^{27}$, Hz. Ali hakkındaki aşırılıkların yanında, teşbih şüphelerini ortaya atan ilk kişidir. Bu tür şüphelerle İbn Sebe, Müslümanları dinlerinde ifsat etmek ve böylece Hıristiyanların İsa hakkındaki anlayışlarına benzer bir anlayışı İslâm'a ithal etmek istemişti ${ }^{28}$.

Tunç, İnsan Yay., İstanbul, 1999, I, s. 331; Resul Öztürk, Cebrî Düşüncenin Yaygınlaşmasında Siyasî İktidarın Etkisi, (AÜSBE Basılmamıs Doktora Tezi), Ankara, 2002, s. 158.

23 Allah'ın sıfatları konusundaki görüşleri ile Mutezile'ye öncülük ettiği iddia edilen Cehm b. Safvân, Allah'ın ezelî sıfatlarının bulunmadığını iddia etmektedir. "Allah, görülecek yüzü, duyulacak sesi, koklanacak bir kokusu olmayan, gözlerin görmediği ve belli bir mekanda bulunmayan bir varlıktır" diyen Cehm b. Safvân'ın görüșleri için bkz., Ahmed b. Hanbel, er-Redd ale'l-Cehmiyye ve'z-Zanâdıka, thk, Abdurrahman Amîre, Riyad, 1982, s. 102 vd; Kasımî, a.g.e., s. 21; Malatî, et-Tenbih ve'r-Redd alâ ehli'l-Ehvâ ve'l-Bida', thk., Muhammed Zâhid el-Kevserî, Bueyrut, 1388/1968, s. 92-96; Sönmez Kutlu, Mürcie ve İtikâdî Görüşleri, (AÜSBE Basılmamış Yüksek Lisans Tezi), Ankara, 1989; R. Öztürk, a.g.e., s. 155-161.

24 İlgili haberler için bkz., Şehristânî, a.g.e., I, s. 96-99.

25 Neşşâr, a.g.e., I, s. 87.

26 Mesela, Tevrat'ta; Allah'ın âlemi altı günde yaratıp yedinci gün dinlendiği (Tekvin: II/2), Hz. Yakup ile güreştiği, Yakub’un onu yenip İsrâil adını aldığından bahsedilmektedir: (Tekvin: 32/ 22-28)

27 Abdullah İbn Sebe ile ilgili geniş bilgi için bkz., Ethem Ruhi Fığlalı, Çağımızda İtikâdî İslâm Mezhepleri, Selçuk Yay., İstanbul, 1993, s. 289-301.

28 Bağdâdî, a.g.e., s. 253. 
Ortada ciddî bir problem vardı ve bu sorunun üstesinden gelebilmek için öncelikle yabancı kültürlere aşina bölge insanının anlayabileceği ve kavrayabileceği bir Tanrı anlayışı ortaya koyabilmek ve tevhid ilkesini zedeleyecek Tanrı anlayışlarının önüne geçebilmek için İslâm dışı inanç ve düşüncelerin ileri sürdükleri iddiaların geçersiz kılınması bir zorunluluk halini almıştı. İşte ilk Kelamcılar olan Mutezile âlimlerinin yabancı din ve düşüncelere karşı yaptıkları mücadele ve yazdıkları reddiyeler ${ }^{29}$, böyle bir faaliyetin fiilen yapıldığının ve büyük ölçüde başarılı olduğunun ${ }^{30}$ belgeleri olarak görülebilir. Nitekim bu dönemde, başta Hıristiyanlık olmak üzere, öteki dinlere reddiye yazanların büyük bir çoğunluğunu Mutezilî âlimler oluşturuyordu $^{31}$. Özellikle Kufe ve Basra'daki ilim meclislerinde daha tabiin döneminden itibaren bu tür fikrî mukavemetin hazırlıkları başlamıştı. Denilebilir ki, Hasan el Basrî (ö. 110/728) ${ }^{32}$ bu tür hareketi ilk ateşleyen düşünür olmuş, öğrencileri olan Vasıl b. Ata (ö. 131/748) ve Amr b. Ubeyd (ö. 143/ 761 ) ise onun sistemini kurup geliştirenlerdi. Muhalifleri tarafindan Mutezile olarak isimlendirilen bu hareket kendilerini Ehlü't-tevhid ve'l-adl ${ }^{33}$ olarak isimlendiriyor ve böylece ilk gündem maddelerinin "Mutlak anlamda bir olan Tanrı anlayışı" olduğunu ilan ediyorlardı.

Genelde halifenin huzurunda gerçekleştirilen dinî içerikli tartışmalar göstermektedir ki, Müslümanlar çok erken dönemlerden beri kendilerinin inançlarını reddeden yüksek kültüre sahip bir halkla aynı coğrafyayı paylaştıklarının farkındadır. Bu coğrafyada Hıristiyan ve Yahudilerden başka Budist ve Hint dinlerinin müntesipleriyle temas halinde olan Müslümanlar, savunma ve polemik ihtiyaçlarının bir gereği olarak felsefe tahsiline girişmişlerdir ${ }^{34}$.

İslâm inancını savunma ihtiyacına ilave olarak, Hıristiyan karşıtı söylemin oluşmasında başka teolojik nedenleri de zikretmek gerekmektedir. İs-

29 Bu dönemde Müslümanların Hıristiyanlara yazdığı reddiyeler hakkında geniş bilgi için bkz., Mehmet Aydın, Müslümanların Hıristiyanlara Yazdığı Reddiyeler ve Tartışma Konuları, TDV Yay., Ankara, 1998; Kaplan, s. 96-128.

30 Karadaş, a.g.e., s 82.

31 David Thomas, Anti-Christian Polemic in Early Islam Abu Isa al-Warraq Against the Trinity, Cambridge Univarsity Pres, New York, 1992, s. 4.

32 Kemal Işık, Mutezile’nin Doğuşu ve Kelâmî Görüşleri, AÜİFY, Ankara, 1967, s. 50; Hasan elBasrî̀nin hayatı ve Kelâmî görüşleri için bkz., Osman Karadeniz, "Hasan el-Basrî ve Kelâmî Görüşleri”, DEÜIFFD, II, İzmir, 1985, ss. 135-156; İbn Murtazâ ise Mutezile'nin doğuşunu Hz. Peygambere kadar dayandırmaktadır; bkz., İbn Murtazâ, Tbakâtu'l-Mutezile, thk., Susanna Diwald-Wilzer, Beyrut, 1961, s. 7.

33 İlâhî adaleti ve Allah'ın gerçek birliğini en iyi şekilde anlayıp ispat ettiklerini düşündükleri için Mutezile'nin en çok beğendiği isim budur; Işık, a.g.e., s. 56.

34 W. Montgomery Watt, İslâm Kelamı ve Felsefesi, çev., Süleyman Ateş, Pınar Yay., İstanbul, 2004, s. 77. 
lam'ı yeni kabul eden mühtedilerin İslam toplumuyla bütünleşmesini sağlama ve önceki inançlarından kaynaklanabilecek bir takım kuşkulardan onları uzaklaștırma, İslam'ın yeni dinî akımlar içerisinde, özellikle de Hıristiyanlık içinde erimesini önlemek için İslam'ın orijinalliğini gösterme gibi sebepler de Hıristiyan karşıtı söylemin oluşmasında etkili olmuşa benzemekte$\operatorname{dir}^{35}$. Aslında bütün bunlar da, Zebirînnin de dediği gibi, Müslüman polemiklerinin Hıristiyanlardan ziyade Müslümanlara hitap eden bir yönünü de gözler önüne sermektedir ${ }^{36}$. Fakat burada polemiklerin oluşmasında, Kur'an'ın en temel ilkesi olan Allah'ın mutlak birliği yani tevhid ilkesini reddeden bütün anlayışlara cevap verme gibi en temel itikadî sebebi tekrar hatırlatmanın yerinde olacağını düşünüyoruz.

O halde, Hıristiyan karşıtı söylemin gerisinde bulunan temel önkabul, "Hakikat bir, batıl ise çoktur" şeklinde dile getirilebilecek anlayıştır diyebiliriz $^{37}$. Watt'ın ifadesiyle özelleştirerek söyleyecek olursak, bunun gerisinde İslam'ın kendi kendine yeterliliğine olan inancı vardır. İslâm'ın bu inancı, İslâmî olmayan her şeyden kuşkulanmaya sebep olmuştur" . "Hak geldi batıl zâil oldu’39 ifadesinden hareketle, zâil olan batıl/batılların ne olduğunu ortaya koyarak, hakkın ne olduğunu belirginleştirme çabası reddiyelerin arakasındaki en temel sebep olarak görünmektedir. Zira, Teolojik söylem, önceden kabul edilen bir fikrin analizine dayanır. ${ }^{40}$ Diğer sebepler bu önkabulün tekrar hatırlanmasına yardımcı olmuştur diyebiliriz.

\section{Politik ve Sosyo-Kültürel Etkenler}

Bütün felsefi ve teolojik mevzuların, siyasi veya sosyal bir dayanağı vardır. Din ile siyasi olaylar arasında yakın bir irtibat her zaman mevcut olmuştur. Eski Ahit bununla doludur. İlk yedi asırda Suriye ve Misır Hiristiyanlarının Bizans İmparatorluğuna karşı nefreti, Monofizit ve Nesturi mezheplerinde mihrakını bulmuştu ${ }^{41}$. Dahası, Teslis doktrininin inançtan değil, politik çı-

35 Abdülmecid eş-Şarfî, el-Fikru'l-İslâmî fîr'r-Redd ale'n-Nasârâ ilâ Nihâyeti'l-Karni'r-Râbii, Tunus, 1986, s. 114.

36 Kate Zebirî, Muslims and Christians; Face to Face, Oxford: Oneworld Publications, 1997, s. 44; Louis Gadret, "İslam Din İlimleri İçinde İlm-i Kelam'ın Yeri Üzerine Bazı Düşünceler”, çev. M. Sait Yazıcıoğlu, (İslam Düşüncesinin Tarihsel Gelişimi, Akçă̆ Yay., Ankara, 2001 içinde), s. 20.

37 Tatar, a.g.m., s. 296.

38 W. Montgomery Watt, "İslâmın Geleneksel Olarak Kendini Görüşü", çev., Turan Koç, Bilgi ve Hikmet, Kıș 1995, S. 9, s. 79.

39 17.İsrâ/81.

40 Zeki Özcan, Teolojik Hermenötik, Alfa Yay., İstanbul, 1998, s. 53.

41 Watt, İslâm Kelamı ve Felsefesi, s. 30. 
karlardan kaynaklandığı iddia edilmektedir ${ }^{42}$. Öyleyse aynı toplumda yaşayan farklı inançlara sahip insanlar arasında meydana gelen tartışmaların da politik ve sosyo-kültürel bir zemini olduğunu söylemek mümkün görünmektedir. Bu bağlamda, gerek Kelam'ın ortaya çıkması ve şekillenmesinde, gerekse Kelam'ın Hiristiyan teolojisine tepkisinde politik ve sosyo-kültürel etkilerin de göz ardı edilmemesi gerekmektedir. Kabul etmek gerekir ki, İslâm dünyasının iç bünyesinde ortaya çıkan bir takım politik ve sosyal hadisler neticede akâid sahasına etki eden amiller haline gelmiştir ${ }^{43}$.

Gerçekleştirilen fetihlerle doğrudan doğruya başlayan Müslüman-Hıristiyan teolojik ilişkilerinde, halifeler de genelde peygamberin onlara karşı takınmış olduğu tavrını ${ }^{44}$ örnek almışlar, Tevbe sûresi 29 . ayetindeki ${ }^{45}$ cizye almaya dair emrini uygulamışlardır ${ }^{46}$. Hz. Ebu Bekir, Necranlıların daha önce Hz. Muhammed'den aldıkları ahidnâmeyi olduğu gibi kabul etmiş ${ }^{47}, \mathrm{~Hz}$. Ömer döneminde Ebû Ubeyde b. Cerrah'ın Şam'da Hıristiyanlarla yaptı̆̆1 sulhnâmede de aynı çizgi korunmuştur ${ }^{48}$. Hz. Ömer Kudüs'ü aldığında, H1ristiyanların cizye karşıllı̆ında can ve mal güvenliklerinin teminat altında olduğu ve ibadethanelerinin yıkılmayacağ 1 garantisini vermişti ${ }^{49}$. Buna karşın, Hz. Ömer'in zararlı faaliyetlerinden dolayı Hıristiyanlara karşı bazı tedbirler aldığı doğrudur. Ancak bu tedbirlerin askerî ve siyasî bir takım şartların zorlamasıyla alındığını söyleyebiliriz ${ }^{50}$. Kaldı ki, Hz. Ömer'in vefatı es-

42 Muhammed Ataurrahim, Bir İslâm Peygamberi Hz. İsa, çev., Kürşat Demirci, İnsan Yay., İstanbul, 1997, s. 13.

43 Yusuf Ziya Yörükan, "İslam Akaid Sisteminde gelişmeler"; AÜiFD, Yll 1952, S. 3, s. 6; Bekir Topaloğlu, Kelam İlmi, Damla Yay., İstanbul, 1998, s. 21; Politik olayların Kelami problemlere etkisi için bkz., Ahmet Akbulut, Sahabe Devri Siyasî Hadiselerinin Kelamî Problemlere Etkileri, Birleşik Yay., İstanbul, 1992, s. 90 vd.

44 Peygamber dönemi Müslüman-Hıristiyan teolojik ilişkileri ve Peygamberin Hıristiyanlara karşı tavrı hakkında geniş bilgi için bkz., Kaplan, a.g.e., s. 55-75.

45 "Kendilerine kitap verilenlerden Allah'a ve ahiret gününe inanmayan, Allah'ın ve elçisinin haram kıldığını haram saymayan ve gerçek dini din edinmeyen kimselerle küçülerek elleriyle cizye verinceye kadar savaşın."

46 Muhammed Hamidullah, Vesâiku’s-Siyâsiyye, Kahire, 1956, s. 157-158.

47 Hamidullah, a.g.e., s. 158.

48 Sulhnâme'ye göre, Hıristiyanlar cizye ödemekle yükümlü tutulurken, şehirlerdeki ve taşradaki kiliselerin yıkılmaması, can ve mal emniyetlerinin sağlanması gibi hususlar garanti altına alınmış, ancak yeni kilise ve havra yapılması yasaklanmıştı; Hamidullah, a.g.e., s 374-375.

49 Hamidullah, a.g.e., s. 379-380; A. S. Triton, The Caliphs and Their non-Muslim Subject; A Critical Study of The Covenant of Umar, Frank Cass\&Co. Ltd., 1970, s. 517.

$50 \mathrm{~Hz}$. Ömer, tefecilikle uğraşmış olmaları ve nüfuslarının kalabalık olması veya gizli bir takım işlere karışmıș olmaları sebebiyle Necranlı Hıristiyanları Irak'a sürmüștür. Yine, toplumdaki gayr-i Müslim unsurların bilinmesini sağlamak için valilerinden zımmîlerin bellerine zünnar bağlamasını sağlamalarını istemiştir; Ayrıntılı bilgi için bkz., Ahmed b. Yahya b. Cabir b. Davud el-Belâzurî, Fütûhu'l-Büldân, çev., Mustafa Fayda, KB Yay., Ankara, 2002, s. 94-95; T.W. 
nasındaki tavsiyelerinden biri, onun zımmîlerin haklarının korunması konusundaki hassasiyetini açık bir şekilde ortaya koymaktadır: "Benden sonra yerime gelecek halifeye, yapılan akitler ve şartnameler mucibince Rasulüllah'in zımmîlerin haklarının tam olarak verilmesini, can ve mallarının emniyeti uğrunda icap ederse savaşılmasını, takatlarının fevkinde yükler yüklenmemesini tavsiye ederim" 1

H. 41 yılında resmen kurulan Emevî Devletinin idarecileri, başta Muaviye (41/60-661-680) olmak üzere, dinî meşruiyet sağlamak için halifetullah unvanını kullanmakla kalmamışlar, cebir ideolojisini de ilk defa bilinçli ve sistemli bir şekilde siyasette kullanmışlardır ${ }^{52}$. Bu dönemde, Hıristiyanlara ve diğer gayr-1 müslim azınlıklara oldukça müsamahakâr davranan Emevî hükümdarlar, kendi iktidarlarının devamını sağlamak için asıl unsur olan Müslüman halka zulüm ve baskı yöntemini kullanmaktan geri durmuyordu. Yaptıkları siyasî kıtaller ve her türlü zulmü meşrulaştırmak için ise Cebrî düşünceyi destekliyordu ${ }^{53}$. Zira Cebrî düşünce, Muaviye'nin iktidarı ele geçirmesi ve insanların da onu ve otoritesini tanımamaları sonucunda ortaya çıkmışt1 ${ }^{54}$. Böylece, hilafet eksenli siyasî kavgalarda dinî nassların meşruiyet kaynağı olarak kullanılmasıyla mürtekib-i kebîre, cebir, kader, istitaât, irade vb konular gündemi işgal etmeye başlamıştı. Söz konusu gündem maddeleri cedel ve münazara tarzındaki tartışmaları başlatmış, sonuçta da karşıtlar arasındaki farklı bakış açılarının cedel mantığıyla işlendiği ideolojik arkaplana sahip ${ }^{55}$ reddiyeleşme geleneğini ortaya çıkarmıştı.

Söz konusu dönemde, Müslümanlar kendi aralarında bu tartışmalarla uğraşırken, Hıristiyanların gayet rahat bir ortamda hayatlarını devam ettirdiklerini görüyoruz. Muaviye ile birlikte devlet idaresinde görev almaya başlayan Hıristiyanların bu müsamaha ortamından alabildiğince yararlan-

Arnold, İntişâr-ı İslâm Tarihi, çev., Hasan Gündüzler, Akçağ Yay., Ankara, 1982, s. 95; Levent Öztürk, İslâm Tolumunda Hiristiyanlar, İz Yay., İstanbul, 1998, s. 210-212, 233.

51 Ebû Abdullah Muhammed İbn Sa'd, Tabakâtu'l-Kübrâ, Dâr'u Sâdır, Beyrut, ty., I, s. 24; Arnold, a.g.e., s. 70; Hz. Ömer dönemindeki zımmilerin sosyal konumları hakkında bir değerlendirme için bkz., Triton, a.g.e., s. 137-145.

52 İbn Murtazâ, a.g.e., s. 6; Emevîlerin bu tür söylemlerine karşı eleştiriler de gecikmemiş, başta Mabed el-Cühenî el-Basrî (80/699) olmak üzere; Gaylan b. Müslim ed-Dimeşkî (105/719), Ca'd b. Dirhem (124/742) ve Cehm b. Safvan (128/746) gibi Müslüman düşünürler sistemli olarak kader meselesinde karşıt bir görüş oluşturmuşlardır; Geniş bilgi için bkz., $\quad$ R. Öztürk, a.g.e., s. 136 vd.

53 Emevî-Cebrî düşünce ilişkisi için bkz., W. M. Watt, İslâm Düşüncesinin Teşekkül Devri, çev., Ethem Ruhi Fı̆̆lalı, Birleşik Yay., İstanbul, 1998, s. 98 vd; Akbulut, Sahabe Devri, s. 281 vd; R. Öztürk, a.g.e., s. 119 vd;.

54 Kâdı Abdulcabbar, Fazlu'l-İtizal ve Tabakâtu'l-Mu'tezile, Dâru't-Tunusiyye, Tunus, 1974, s. 163.

55 İbrahim Aslan, Hasan b. Muhammed'in Cebir Risalesi ve Yahya b. Hüseyin'in Reddiyesinin Mukayeseli Değerlendirilmesi, (AÜSBE Yüksek Lisans Tezi), Ankara, 2002, s. 8. 
mış olduğu anlaşılmaktadır. Amr ibn As'ın m. 639 yılında Antakya Nesturî patriği I. John ile başlattığı tartışmaların ${ }^{56}$ Emevî saraylarına taşınmış olması Hıristiyanlara gösterilen müsamahanın boyutlarını ifade etmesi açısından önemli görünmektedir. Bu dönemin en ünlü Hıristiyan polemikçilerinden Yuhanna ed-Dımeşkî Emevî saraylarında görev yapmıştı. Dımeşkî ve talebesi Theodora Ebu Kurra'nın apolojileri bu müsamaha ortamının ürünüdürler.

Gayr-1 müslim azınlıklara gösterilen toleranslı anlayış, temelde değişmemek şartıyla, Ömer b. Abdülaziz (707-720) tarafından bazı tedbirlerin alınmasıyla bir anlamda kısıtlanmıştır ${ }^{57}$. Temel hak ve özgürlükleri koruyarak, toplumdaki nizam ve intizamın sağlanmasına yönelik bu tedbirlere sebep olan yine Hıristiyanların siyasî ve sosyal hayat tarzları olmuştur. Gayr-1 müslimlerin kendilerine gösterilen müsamahayı ve işgal ettikleri sosyal statüleri kötüye kullanmaları, Müslüman halka kaba davranmaları ve Müslümanları rahatsız etmeleri bazı tedbirlerin alınmasını zorunlu kılmışt $1^{58}$.

Fakat, İslam toplumunda yaşayan zımmîlere, kılık-kıyafet, vergi, mabet vb konularda ${ }^{59}$ baskı uygulandığını iddia eden pek çok Batılı bilim adamının hiçbirisi fikir hürriyeti açısından herhangi bir baskıdan söz etmemişledir. Dolayısıyla, İslam toplumunda yaşayan gayr-i müslimler kendi inanç ve değerlerini savunma ve tartışma gibi özgürlüklerini sonuna kadar kullanmışlardır ${ }^{60}$. Buna ilaveten, iktidarı ele geçirenin karşı tarafa tahammülsüzlüğüne, hatta sert tedbirlere başvurmaktan çekinmemesine rağmen, gayr-1 Müslimlere gösterilen aşırı müsamaha halkın vicdanını ciddî şekilde yaralamışa benzemektedir. Netice olarak halk bu tepkisini farklı şekillerde dile getirmiş olmalıdır.

Bu tür şikayetlerle el-Mansur (754-775), el-Mehdî (775-785), el-Me'mun (815-833), el-Mütevekkil (847-861) ve el-Muktedir (908-932) gibi halifeler de karşılaşmışlar, gayr-1 müslimlere karşı sert olmayan bazı kısıtlamalara gitmişlerdir. Harun Reşid (786-809) ve bilhassa el-Mütevekkil (847-

56 Geniş bilgi için bkz., F. Nau, "Dialogue Between the Patriarch John I and Amir of the Hagarenes", A Collection of Documents from the First Three Islamic Centuries (632-900 AD) Translation with Commentary, ed. by., N.A. Newman, İnterdisciplinary Biblical Research Institute, Harfielde, Pennsylvania, 1993, ss. 11-46; Kaplan, a.g.e., s. 98-99.

57 Bu tedbirler daha ziyade onların tanınmasını sağlayan kılık-kıyafet, hareket tarzları ve İslam hizmetlerinde onların kullanılmaması şeklindeki din özgürlüğüyle alakalı olmayan sosyal içerikli tedbirlerdir.

58 Arnold, a.g.e., s. 90-91.

59 Bu konulardaki uygulamaların detayları için bkz., L. Öztürk, a.g.e., s. 102 vd.

60 Ignaz Goldziher, "Ehl-i Kitab’a Karşı İslam Polemiği”, çev., Cihat Tunç, AÜİFD, C. V, s. 154; David Thomas, "The Doctrin of the Trinity in the Early Abbasid Era", Islamic Interpretations of Christanity, ed., Lloyd Ridgeon, Curzon Pres, Richmond, 2001, s. 78; L. Öztürk, a.g.e., s. 263. 
861) döneminde ise bu kısıtlama ve tedbirlerin uygulandığına şahit olmaktayız $^{61}$. Fakat, görünen o ki, bu tedbir ve kısıtlamalar da zımmîlere uygulanan hukukun tekrar düzenlenmesi ve hatırlatılmasından ibaret kalmıştır. Zımmîlerden, beyaz elbise giymeleri ve zünnar bağlamaları, Müslümanlardan daha büyük binalar yapmamaları, çanlarının sesini ve kendi kitaplarının okunuşunu daha sessiz yapmaları, haç ve putlarını, domuzlarını ve içki içişlerini Müslümanlara göstermemeleri vb. istenmektedir ${ }^{62}$. Fakat bu kısıtlamalar ve tedbirlerin din hürriyeti açısından değil, sosyal şartlar açısından gerekli zaruretler ${ }^{63}$ olarak düşünülmesi daha doğru olur.

İşte İslam idarelerinin dinî müsamahası içinde tartışma imkanı bulan Hıristiyanlar bu sert idareler altında sinmek zorunda kaldılar. Fakat ilginçtir ki, hem 1lımlı ortam hem de tedbirlerin alındığı sert ortam bu dönemde oluşmaya başlayan Hıristiyan karşıtı reddiye geleneğinin gelişmesine önemli katkılar sağlamıştır ${ }^{64}$. Abdullah b. İsmail el-Hâşimî’nin Abdü'l-Mesih el-Kindî'yi İslam'a davet ettiği, onun da buna yazdığı reddiyeleri birinciye örnek olarak verilebilir. Yine, Timotheus ile halife el-Mehdî arasındaki tartışma da müsamaha ortamının bir ürünüdür. İkinciye ise, Ali b. Rebban et-Taberî̀nin ed-Dîn ve'd-Devle isimli eserini örnek gösterebiliriz. Nitekim, Taberî, bu eserini Halife el-Mütevekkil'in teşvikiyle yazdığını belirtmektedir ${ }^{65}$.

Zaman zaman bazı tedbirlere ve yasaklamalara rağmen, Abbasîler döneminde de aslında azınlıkların özgürlükleri anlamında değişen fazla bir şey olmamıştır. Hatta, zamanla sosyal refah seviyeleri ve toplumdaki nüfuzları artan Hıristiyanlar, bu dönemde, gerek saraylarda gerekse toplumun değişik kesimlerinde kendi inançlarını dile getirebilme ve savunabilme özgürlügüünden daha fazla yararlanmışlardır. Saraylardaki ve entelektüel çevrelerdeki bu tartışma toplantıları zaman zaman Müslümanlara adeta ikinci sınıf vatandaş durumuna düşme kaygısı yaşatacak kadar Hıristiyanlarla samimiyeti beraberinde getirmiştir. Bu tür kaygılar da bir anlamda sessiz bir protesto mahiyetindeki reddiyelerin oluşumuna önemli bir katkı sağlamıştır ${ }^{66}$.

61 İbn Cerîr et-Taberî, Tarîhu'l-Ümem ve'l-Mülûk, thk., M. Ebu'l-Fadl İbrahim, Dâru's-Seveydân, Beyrut, ty., IX, s. 171; Arnold, a.g.e., s. 91

62 İbn Cerîr et-Taberî, Tarîhu'l-Ümem ve'l-Mülûk, s. 171-173; L. Öztürk, a.g.e., s. 185 vd.

63 Aydin, a.g.e., s. 30.

64 Aydin, a.g.e., s. 30-31.

65 Ali b. Rabbân Taberî, ed-Dîn ve’d-Devle,,thk., Adil Nüveyhiz, Dâru'l-Efkâru'l-Cedîde, Beyrut, 1982, s. 209.

66 L. Öztürk, a.g.e., s. 266; Sidney H. Griffith, "Faith and Reason in Christian Kalâm: Theodora Abû Qurrah on Discerning The True Relgion", Christian Arabic Apologetics During the Abbasid Perod, ed., Samir Khalil-Jorgen S. Nielsen, E.J. Brill, Leiden-New York-Köln, 1994, s. 1-2. 
Görünen o ki, Hıristiyanların Müslüman toplum içindeki konum ve itibarları, bunun yanında misyonerlik olarak adlandırılabilecek faaliyetleri halkın tepkisine sebep olmuştur. Halk bu tepkisini bizzat saraya ilettiği gibi dönemin aydınlarından da bu konuda yardım ve destek talebinde bulunmuștur. Câhız'ın reddiyesi bu kanaatimizi güçlendirmektedir.er-Redd ala'nNasârâ adlı eserinde Hıristiyanların toplumdaki nüfuzlarından şikayet eden Câhız, söz konusu eserini bazı Müslümanlardan gelen sorulara açıklık getirmek için yazdığını söylemektedir ${ }^{67}$. Câhız'n reddiyesinin Mütevekkil'in gayr1 müslimlere yönelik olarak alınan siyasî kararları ile irtibatı konusunda bir bilgiye sahip değiliz. Ancak, bu eserin Mütevekkil'in kararlarından önce yazılmış olduğunu düşünürsek, söz konusu reddiyenin kamuoyu oluşturmada katkı sağlamış olabileceğini söyleyebiliriz. Nitekim, Cahız'ın reddiyesinde yer alan, "Hıristiyanların Müslümanlar gibi giyindikleri" şeklindeki bir bilgiden ve H1ristiyanların toplumdaki etkilerine işaret eden gözlemlerinden ${ }^{68}$ hareketle, eserin Mütevekkil'in kararlarından önce yazılmış olduğunu söyleyebiliriz. Bir diğer ihtimal ise, Câhız'ın 255 yılında öldüğünü göz önünde bulundurulursa, onun bu tür şikayetlerinin alınan kararların uygulanmasında gösterilen ihmallerin sonucu olduğudur ${ }^{69}$. Fakat görünen o ki, ister söz konusu kararlardan önce yazılmış olsun, isterse daha sonra yazılmış olsun, Câhız bu eseriyle, Müslümanlar tarafından dile getirilen tepkilerin sözcüsü olmuştur.

Kısaca belirtmek gerekirse, bir yandan reddiyelerin oluşturduğu komuoyu, diğer taraftan da halkın tepki ve sözlü uyarıları Hıristiyanlara karşı daha sert tedbirlerin alınmasına sebep olduğu gibi bizzat halifeler tarafından H1ristiyan karşıtı reddiyelerin yazdırılmasına da yol açmıştır. Bu da devletin Müslüman olmayanlara karşı uyguladığı politikaları meşrulaştırma ihtiyacının bir sonucu olarak görülebilir ${ }^{70}$.

Bunun yanında, aynı toplumda Hıristiyanlarla bir arada yaşayan Müslümanlar onların dinleri hakkında bilgi edinme ihtiyacı hissetmişler, yine onları İslam'a davet etmek için inanışlarının yanlış ve eksik taraflarını öğrenmek ihtiyacı hissetmişlerdir. Ayrıca, asırlardır süregelen mezhep kavgalarından bunalarak İslam'ı tercih etmiş olan muhtedîler İslam imanının ilk heyecanı içinde hemen eski dinlerini tenkid mahiyetinde bir takım risaleler kaleme almışlardır ${ }^{71}$.

67 Ebû Osman Amr b. Bahr el-Câhız, el-Muhtâr fi'r-Redd ale’n-Nasârâ, thk., Muhammed Abdullah el-Şarkâvî, Dâru'l-Cîl, Beyrut, 1991, s. 53.

68 Câhız, a.g.e., s.74-76

69 Geniş bilgi için bkz., L. Öztürk, a.g.e., s. 270.

70 Şarfî, a.g.e., s. 112

71 Günümüze kadar ulaşan reddiyeler içinde bir mühtedî tarafından kaleme alınmış ilk reddiye 
Goldziher, Müslüman toplumda Hıristiyan karşıtı söylemin oluşmasını farklı bir açıdan değerlendirmektedir. Ona göre, Arapların önceden sahip oldukları polemikçi mizaç onların düşünce yapılarına da yansımış, edebiyatları da bu mizaca uygun bir tarzda gelişmiştir. Öyle ki, gece ile gündüz, kalem ile kılıç, Kahire ile Dimışk, elif ile bâ bile polemik konusu yapılmış, karşılıklı deliller ileri sürülmüştür. Ona göre, İslâm'ın mütecaviz tabiatı Arapların bu temayülünü dini sahada geçerli kılmaya sevk etmiştir. Polemik tarzı yazıların başlangıcının İslâm'ın ilk devirlerine kadar gittiğini, zira Ehl-i Kitaba karşı İslâm polemiğinin en eski kitabının Kur'an'ın kendisi olduğunu ${ }^{72}$ belirten Goldziher, Arapların bu polemikçi mizaçlarının İslâmiyetle birlikte dinî bir özellik kazandığını söylemiştir ${ }^{73}$.

Polemik geleneğinin oluşmasında daha önce açıklamaya çalıştı̆̆ımız etkiler, bu durumu Arapların polemikçi mizaçlarına ya da İslâm'ın mütecaviz tabiatına bağlamanın yetersizliğini ortaya koymaktadır. Zira, polemik geleneğinin gelişmesi için neden H. III. asrın başlarını beklediği sorusunun cevabı, Kelamın bu dönemde işlevi açsından neden argümantasyon tarzına müracaat ettiğinin cevabını da verecektir. Yine, İslâm coğrafyasında teşekkül eden erken dönem itikadî ve siyasî oluşumların neredeyse tamamının Irak bölgesinde ortaya çıkmış olmas1 ${ }^{74}$, sözü edilen döneme ilişkin Kelamın fonksiyonu, muhtevası ve yöntemi hakkında önemli ipuçları sağlamaktadır.

Bölgenin çok kültürlü ve çok dinli yapısı, bölgeye yeni gelen ve değişik şartlarla karşılaşan Müslümanların bu şartlar doğrultusunda davranmasını, tedbir almasını ve bölgeye uygun yaşam tarzı geliştirmesini zorunlu kılmış$\operatorname{tır}^{75}$. Pek çok din ve Tanrı tasavvuruyla karşılaşan Müslümanlar, İslâm'ın esaslarını ve Tanrı tasavvurunu açıklamak için kaçınılmaz olarak diğer sistemlerle karşılaştırma yapmak yoluna gitmek zorunda kalmışlar, bu da argümantasyon tarzını kullanmayı gerektirmiştir. Bölgede en çok müntesibi olan dinin Hıristiyanlık olması ise daha çok bu dinin muhatap alınmasına, bölgede Hıristiyanlığı temsilen çoğunlukla Melkit, Nesturî ve Yakubîlerin bulunması da özellikle bu mezhepler yoluyla Hıristiyanlığın tenkide tabi tutulmasina sebep olmuştur.

olma özelliği Ali b. Rabbân et-Taberînnin er-Redd ale'n-Nasârâ adlı eserine aittir. Müellif bu eserini samimî olduğunu göstermek için kaleme aldığını belirtmektedir. Ali b. Rabbân et-Taberî, ar-Radd ala-n-Nasârâ de Ali At-Tabari, (edite par) I. A. Khalife-W. Kutsch, MUSJ, Bayrout, 1959, Toma, XXXVI, Fas. 5, s. 119.

72 Goldziher, a.g.m., s. 154.

73 Goldziher, a.g.m., s. 152.

74 W. Montgomery Watt, İslâm'da Siyasi Düşüncenin Oluşumu, çev., Murat Kılavuz, İstanbul, 2001; Cağfer Karadaş, "Mu'tezile Kelam Okulunun Oluşum ve Gelişim Süreci”, Marife, 3/3, Kış 2003, s. 9.

75 Karadaş, a.g.m., s. 9. 


\section{Tercüme Hareketleri}

Müslümanlarla Hıristiyanlar arasındaki teolojik ilişkiler sürecini üç safhada ele almak mümkün görünmektedir. Birinci safha, her iki din mensubunun da iddialarını desteklemek için kendi kutsal metinlerinin otoritesine başvurduğu dönemi ve anlayışı yansıtmaktadır. Bu süreç tarihî olarak, Kitab-1 Mukaddesin Arapçaya çevrilmeden önceki dönemini ifade etmektedir. Sözü edilen dönemde Müslüman düşünürler, Kur'an'ın Hıristiyanlık hakkında verdiği bilgileri Hıristiyanların kendi kutsal kitaplarına müracaat ederek destekleme gibi bir şansa sahip değildi ${ }^{7}$. Dolayısıyla bu dönemde Hıristiyanlık hakkındaki bilgiler Kur'an'ın verdiği malumatla sınırlı kalıyordu. Hz. Muhammed'in davet mektupları, Patrik John ile İslâm komutanı arasındaki tartışma bu dönemde Hıristiyanlık hakkındaki bilgilerin Kur'an'1 Kerim'im muhtevasıyla sınırlı kaldığııı gösteren örnekler olarak değerlendirilebilir.

Fetihlerle birlikte İslâm coğrafyasının genişlemesinden sonra, fethedilen bölgelerde yaşayan gayr-i müslimler yavaş yavaş Arapçayı öğrenmeye başladılar. İmparatorluk merkezlerinde yaşayan gayr-i Müslim düşünürler ise Arapçayı daha hızlı bir şekilde öğrenme gayretinde idiler. Bunlar, daha sonra hem Kur'an'ı incelemeye, hem de kutsal metinlerini Arapçaya çevirmeye başladılar. Böylece, her iki tarafın polemikçileri kendi iddialarını güçlendirmek için hem kendi kutsal kitaplarından hem de diğer tarafın kutsal metinlerinden delil getirme yoluna gittiler. Böylece, teolojik ilişkilerin bu ikinci safhasında, her iki taraf için de ötekinin kutsal kitabı kendi iddialarını delillendirmenin bir vasıtası olmaya başladı. Bu dönemde özellikle mühtedilerin önceki dinlerini terk ederek neden İslâm'ı seçtiklerini açıklamak gayesiyle yazdıkları reddiyelerde önceki dinlerinin kutsal kitaplarına sık sık müracaat ettiklerine şahit olmaktayız ${ }^{77}$. Bu yöntemi ilk kez Ali b. Rabbân et-Taberî kullanmış ve kendinden sonra gelen polemikçilere bu konuda örneklik teşkil etmiştir.

Üçüncü safha ise, tercüme hareketlerinden sonra ortaya çıkmıştır denilebilir. Abbasî halifesi el-Me'mun tarafından 830 yılında Bağdat'ta kurulan Beytü'l-Hikme'nin temel amacı, felsefe, kimya, tıp, astronomi, astroloji ve matematik alanlarında Yunanca ve Süryanice eserleri Arapçaya çevirmek $\mathrm{idi}^{78}$. Bu alanlardaki eserlerin Arapçaya çevrilmesinden sonra Müslüman

76 Wadi Z. Haddad, “A Tenth-Century Speculative Theologian's Rafutation of the Basic Doctrines of Christianity: al-Baqillani”, Christian-Muslim Encounters, ed., Y. Y. Haddad and W. Z. Haddad, University Press of Florida, 1995, s. 84; Tatar, a.g.m., s. 295.

77 Haddad, a.g.m., s. 84; Tatar, a.g.m., s. 295.

78 Abbasilerin iktidara gelişinden, Me'mun'un tahta oturmasına kadar geçen süre içinde de oldukça fazla sayıda eser, Yahudiler, Hıristiyanlar ve İslâmiyet dışındaki dinlerden son zamanlarda ihtida etmiş olan mütercimler tarafından Arapçaya çevrilmiştir. Dolaysıyla tercüme hareketlerine, Abbasilerin iktidara gelmesinden Me'mun dönemine kadar olan safha ve bu tarihten 
düşünürler, ilk elden bu eserler hakkında bilgi sahibi olmaya başladılar. $\mathrm{Bu}$ oluşum, Müslümanlarla Hıristiyanlar arasındaki tartışmalarda Aristo felsefesi ve mantığının ortak bir zemin olmasını beraberinde getirdi ${ }^{79}$. Böylece her iki taraf da kendi dinî mesajlarının aklîliğini ispatlama sadedinde felsefî terimlerin yardımına müracaat ettiler. Bu noktada öne çıkan en önemli konular ise, teslis ve inkarnasyonun Tanrı'nın birliği açısından nasıl izah edilebileceği idi ${ }^{80}$. Bu anlamda, Aristo mantığını teslis inancının tutarsızlığını ortaya koymak için kullanan ilk düşünür Kindî olmuştur ${ }^{81}$.

Tercüme hareketleri sonucunda İslâm dünyası, başta Platon, Aristo Sokrates, Proclus, Plotinus, Galenus gibi Grek, Yeni Platoncu ve Yeni Pisagorcu filozofları eserleri ve eserlerinde tercüme edilen fragmentleriyle tanıyorlard. Bunun yanında, Thales, Anaximenes, Aneximandros, Parmanides, Elealı Zenon, Anaxagoras, Empedokles, Demokritos ve Kukippos gibi filozofları onlara izafe edilen hikemî sözlerden oluşan parçalarıyla tanıyorlard $1^{82}$. Bu ve başka eserlerin tercümesiyle birlikte bir yandan çok Tanrıcı Grek Panteonunun getirdiği sorunlar, diğer yandan Helenistik dönemde Grek felsefesiyle iç içe girmiş olan Hıristiyan teolojisinin, özellikle doğu kiliseleri tarafından dile getirilen problemleri İslam dünyasında tartışılmaya başlandı. Bundan sonra Müslüman düşünürler bu tartışmalar hakkında derinliğine araştırma yapma ihtiyacı hissettiler. Zira, son ilâhî mesaj olan Kur'an'ın tasdik etmek üzere geldiğini belirttiği Tevrat ve İncillerde ortaya konulan muharref Yahudi-Hıristiyan geleneğine ve her türden antropomorfizme kapıları kapayan saf tevhid akidesini, Helenistik dönemde şekillenen muhtelif politeist anlayışlara karşı savunabilmek ve çok yönlü mukayeseler yapabilmek için öncelikle bu tartışmalar hakkında derinlemesine bilgi sahibi olmak gerekiyordu. Dolayısıyla, tercüme faaliyetlerinin başlamasında, Müslümanların İslâmiyet'i delillerle savunma ve karşı durdukları kültürleri tanıma gayretlerinin önemli bir etkiye sahip olduğunu söyleyebiliriz ${ }^{83}$. Bu anlamda, tercüme faaliyetleri Müslüman-Hıristiyan teolojik ilişkilerine, dolayısıyla da

sonraki safha olarak iki safhada değerlendirmek gerekmektedir. Ancak gerçek manada tercüme hareketinin Me'mun'la birlikte başladığı kabul edilmektedir. De Lacy O’leary, İslâm Düşüncesi ve Tarihteki Yeri, çev., Yaşar Kutluay-Hüseyin Yurdaydın, Pınar Yay., İstanbul, 2003, s. 105-106; Bekir Karlığa, İslam Düşüncesinin Batı Düşüncesine Etkisi, Litera Yay., İstanbul, 2004, s. 219.

79 Seppo Rissanen, Theological Encounter of Oriental Christians with Islam During Early Abbasid Rule, Abo Akademi University Pres, Abo, 1993, s. 76.

80 Rissanen, a.g.e., s. 77-78.

81 Haddad, a.g.m., s. 84; Tatar, a.g.m., s. 295-296.

82 Karlığa, a.g.e., s. 223; Ayrıca geniş bilgi için bkz., Hilmi Ziya Ülken, Uyanış Devirlerinde Tercümenin Rolü, Ülken Yay., İstanbul, 1997, s. 87 vd; O’leary, a.g.e., s. 105-119; İbrahim SarıçamSeyfettin Erşahin, İslâm Medeniyeti Tarihi, TDV Yay., Ankara, 2006, s. 35-42.

83 Sarıçam-Erşahin, a.g.e., s. 37. 
Kelam çalışmalarına yeni bir dinamizm kazandırmıştır denilebilir. Saf tevhid ilkesini koruma amacı için Müslüman düşünürler, bir yandan geleneksel kutsal kitap yorumlarından fazlaca etkilenen Tefsir çabalarını (İsrâiliyât) sıkı denetim altına almaya çalışırken, diğer taraftan da bu ilkeyi dejenere etme eğilimi gösteren hadis uydurma faaliyetlerini engellemek üzere sistematik çalışmalara hız verdiler ${ }^{84}$. Kelamcıların hadis olarak rivayet edilen haberlerin bilgisel değeri konusunda gösterdikleri titizliğin arkasında yatan sebeplerin başında yukarıda ifade ettiğimiz kaygıları yatmaktadır diyebiliriz.

\section{Sonuç}

Yeni fethedilen bölgelerin çok kültürlü ve çok dinli yapısı, bölgeye yeni gelen ve değişik şartlarla karşılaşan Müslümanların bu şartlar doğrultusunda davranmasını ve tedbir almasını gerektiriyordu. Fethedilen bölgelerde pek çok din ve Tanrı anlayışıyla karşılaşılması, İslâm'ın esaslarını ve Tanrı anlayışını açıklamak için diğer sistemlerle karşılaştırma yapmayı kaçınılmaz kılıyordu. Bölgede en çok müntesibi bulunan dinin Hıristiyanlık olması ise daha çok bu dinin muhatap alınmasını gerektiriyordu. Bu anlamda, gerek diğer dinlere, gerekse Hıristiyanlığa karşı yazılan reddiyeler, karşılaştırmalar yaparak İslâm'ın inanç esaslarını bölge insanına tanıtma çabalarının bir ürünü olarak görülebilir. Bunun yanında, İslâm'ı yeni kabul edenlerin İslâm toplumuna entegrasyonunu sağlama ve önceki inançlarından kaynaklanabilecek kuşkulardan onları uzaklaştırma, İslâm'ın yeni dinî akımlar içerisinde, özellikle de Hıristiyanlık içinde erimesini önlemek için İslâm'ın özgünlügünü gösterme gibi sebepler de polemik tarzı eserlerin ortaya çıkmasını hazırlayan etkenler olarak zikredilebilir. Ayrıca, İslâm'ı tercih etmiş olan mühtedilerin eski dinlerinin tutarsızlıklarını ortaya koyma çabaları Hıristiyan karşıtı literatürün oluşmasına önemli katkılar sağlamıştır. Ancak, polemiklerin oluşmasında Allah'ın Mutlak Birliği yani tevhid ilkesini reddeden bütün anlayışlara cevap verme gibi temel itikâdî sebep göz ardı edilmemelidir.

Bir nedene değil de pek çok nedene bağlı olarak Müslüman Kelamının gündemine giren Hıristiyanlık, özellikle reddiyelerde ayrıntılı bir şekilde ele alınmış, tevhide dayalı Tanrı anlayışıyla çelişik hususları ortaya konulmak suretiyle eleştiri konusu yapılmıştır. Hıristiyanlığın inanç esaslarının, özellikle de tevhide dayalı Tanrı anlayışıyla çelişik yönleriyle tanıtılması ihtiyac1, bir anlamda bölgede bulunan Hıristiyanların misyonerlik olarak adlandırılabilecek faaliyetlerine tedbir olarak da düşünülebilir. Zira, dün de bugün 
de Hiristiyan misyonerler, Kur'an'daki Hz. İsa'dan "Allah'ın Kelimesi” olarak ve Hıristiyanlardan olumlu vasıflarla bahseden ayetlere işaret ederek, Hıristiyanlığın da makbul bir din olduğunu iddia etmektedirler. Bu da, cahil Müslümanların kafasını karıştırmaktaydı. Bu bağlamda hem şüpheleri gidererek dini savunma ve dindarın imanını güçlendirme hem de kitlesel islâmlaşma neticesinde ortaya çıkabilecek sorunlara çözüm üretebilme anlamında bir sorumluluk yüklenmiş olan ilk Kelamcılar, Hıristiyanlarla fikrî mücadelede, oluşan şartlara göre farklı üslûplar geliştirmişlerdir. Farklı üslüplara ve zengin bir içeriğe sahip olan, genelde Mutezilî kelamcılar tarafından yazılmış olan reddiyeler, Kelam tarihinin ilk dönemine 1 şı tutacak belgeler olarak durmaktadır. 